\title{
Effects of Ultraviolet Rays and Temperature on Spider Silks
}

\author{
Shigeyoshi OSAKI ${ }^{1)}$
}

\section{大㠃茂芳1)：蜘蛛糸に及ぼす紫外線および温度の影響}

\begin{abstract}
Effects of ultraviolet rays and temperature upon drag lines of mature spider Argiope amoena were studied by the electron spin resonance ESR method. The relative signal intensity as a measure of decomposition of protein molecules increased at room temperature with irradiation time of ultraviolet rays. This shows that the protein molecules constituting drag lines were decomposed by the ultraviolet rays. The signal intensity without ultraviolet rays decreased gradually to $100^{\circ} \mathrm{C}$, above $100^{\circ} \mathrm{C}$ increased, and then showed a peak at about $170^{\circ} \mathrm{C}$. The peak may come from the superposition of two factors such as an increase in radicals ascribed to chemical decomposition at high temperatures and a decrease in radicals ascribed to the enhancement of molecular motion of silk protein.
\end{abstract}

\section{Introduction}

Drag lines secreted out of the spider body have been studied from mechanical, physico-chemical, thermal, and optical points of view (e.g. WORK, 1976; WORK \& MOROSOFF, 1982; GOSLINE, 1984; OSAKI, 1989a; 1989b). The drag lines are necessary for the spider to move, prey insects and make orb-webs (OSAKI, 1996). The orb-web is irradiated outdoors by ultraviolet rays. On the other hand, it is well known that the spider silks stuck on some objects such as rock or metal fences in summer should be heat-stable even at high temperatures between $60^{\circ} \mathrm{C}$ and $100^{\circ} \mathrm{C}$. Thus, it is interesting to study the effects of this irradiation and temperature upon spider silks. We have reported the seasonal changes in their amino acid composition (OSAKI, 1989a), in color of drag lines (OSAKI, 1989b), and in the thermal property of drag lines (OSAKI, 1989a). In a previous paper (OSAKI, 1994) we reported the aging of spider silks based on the effect of ultraviolet rays upon the drag lines secreted at different life stages of the spider Nephila clavata L. KосH, 1878. No reports, however, are yet available on the decomposition of drag lines of the spider Argiope amoena L. KoCH, 1878, induced by the temperature and ultraviolet rays.

The present paper describes the effects of ultraviolet rays and temperature upon the drag lines of mature spider Argiope amoena by the electron spin resonance ESR method.

\section{Materials and Method}

Samples used here were drag lines secreted out of mature female spider A. amoena collected in August in Kochi prefecture. The drag lines were automatically wound

1) Shimane University, Matsue, Shimane 690, Japan

島根大学, 干 690 松江市西川津町 1060

Accepted March 31, 1997 
around a rectangular frame at a rate of about $20 \mathrm{~cm} / \mathrm{sec}$. The ESR spectra were measured by JES-FEIX (JEOL, Japan), with ultraviolet rays (containing UV-A, UV-B and UV-C) irradiated from the high pressure mercury lamp of 500 watts. The energy irradiated to the sample from the lamp was estimated to be about $1.2 \mathrm{MJ} / \mathrm{m}^{2}$. The temperature of the quartz cell containing a silk sample with ca. $1.5 \mathrm{mg}$ was raised stepwise at different temperatures for ESR measurements. The $\mathrm{Mn}^{2+}$ signals were used for the reference of ESR signals.

\section{Results and Discussion}

Figure 1 shows ESR spectra measured just after the ultraviolet rays were irradiated for different minutes to the drag lines secreted out of female $A$. amoena abdomen. The magnetic field applied to the sample was 3360 gauss \pm 50 gauss and the $g$ value was determined to be 2.003 for the observed radical. It was well known that the ultraviolet rays induce the breaking of chemical bonds in protein molecules (OSAKI, 1994). Since the signal intensity in the ESR spectrum expresses the quantity of radicals due to the chemical decomposition of silk protein, the increase in the signal intensity may correspond to that in the degradation of the drag lines.

Figure 2 shows the relative signal intensity, which is defined as a ratio of the signal intensity at a given time to the signal intensity at an initial time, for drag lines of female $A$. amoena appearing in Fig. 1 plotted against irradiation time of ultraviolet rays. The relative signal intensity for drag lines of the female $A$. amoena initially increases gradually with irradiation time and then approaches to an aymptotic value, as shown in Fig. 2. This means that the protein constituting the drag lines decomposes chemically by the irradiation of ultraviolet rays. Though the asymptotic value for A. amoena is a little higher than that for $N$. clavata, this behavior is similar to that obtained for the drag lines of $N$. clavata (OSAKI, 1994).

Figure 3 shows the temperature dependence of signal intensity, which is defined as a ratio of the signal intensity of protein radical to the signal intensity of $\mathrm{Mn}^{+2}$ radical at a given temperature, for drag lines of female A. amoena. Between room temperature and $100^{\circ} \mathrm{C}$ the radical without irradiation of ultraviolet rays decreases gradually with

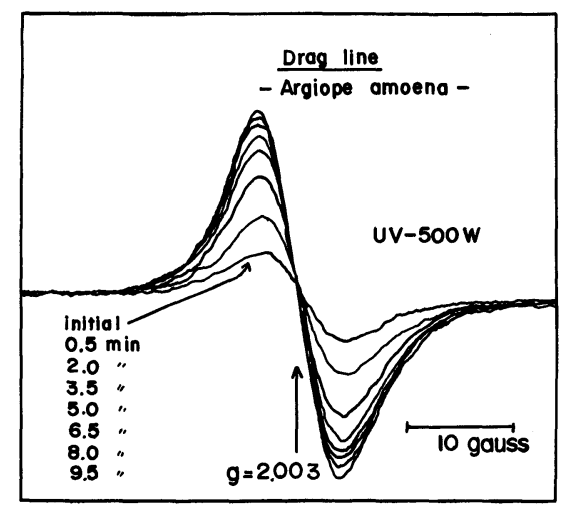

Fig. 1. Spectra of ESR for drag lines of mature female spider Arigope amoena collected in August at differnt irradiation times of ultraviolet rays. The $g$ value was 2.003 . 


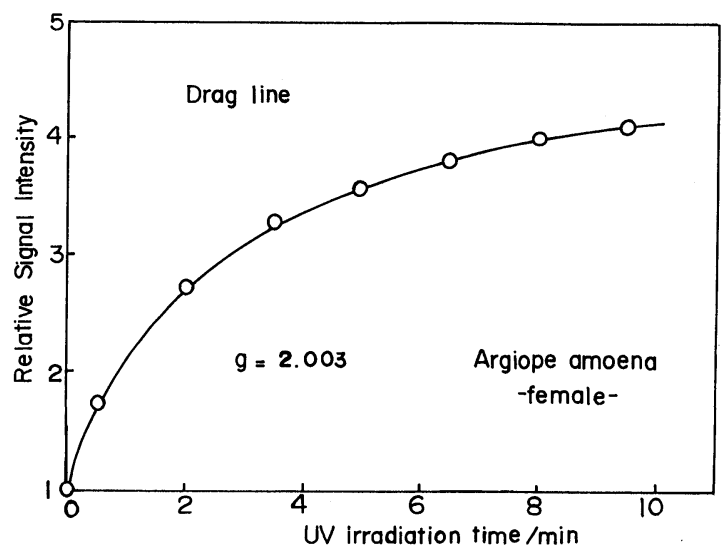

Fig. 2. Time dependence of relative signal intensity under ultraviolet ray irradiation measured by ESR for drag lines of female Argiope amoena.

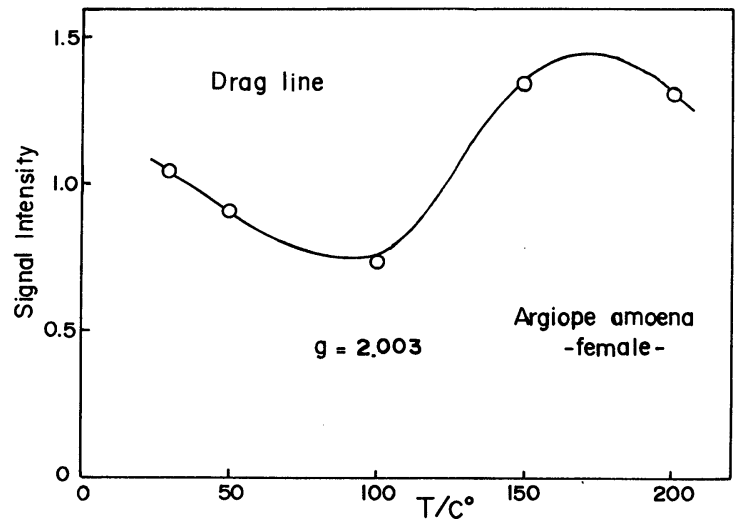

Fig. 3. Temperature dependence of signal intensity measured by ESR for drag lines of female Argiope amoena. The signal intensity is defined as a ratio of the signal intensity of protein radical to signal intensity of $\mathrm{Mn}^{+2}$ radical at a given temperature.

increasing temperature. Above $100^{\circ} \mathrm{C}$ the radical increases gradually and then shows a peak at about $170^{\circ} \mathrm{C}$. Between room temperature and $100^{\circ} \mathrm{C}$ the radicals are apt to combine each other and diminish with increasing temperature. Above $100^{\circ} \mathrm{C}$ the radicals are produced by thermal degradation. The signal peak at about $170^{\circ} \mathrm{C}$ may come from the superposition of two factors such as an increase in radical due to thermal decomposition and a decrease in radical due to molecular motion of protein at high temperatures. It was found that the radical intensity produced at high temperatures was much smaller than that induced by the irradiation of ultraviolet rays.

From the results described above, we have concluded that the proteins constituting drag lines of $A$. amoena were decomposed chemically by an irradiation of ultraviolet 
rays, and that the effects of not only production but also extinction of radicals should be considered, based on the enhancement of molecular motion of protein at high temperatures to $200^{\circ} \mathrm{C}$

摘要

成熟したコガネグモの牽引系に及ぼす紫外線および温度の影響を ESR 測定法で調べ た。室温で紫外線を照射して生じるタンパク質分解ラジカルは，照射時間とともに増大 することが確認された。 また，ラジカル強度は，100ㄷまでは温度とともに減少するが， それ以上の温度では増大し, $170^{\circ} \mathrm{C}$ 付近で極大を示した.このラジカル強度の極大は, 温 度上昇によってタンパク質の分解が促進される影響と，高温で分子運動が活発化するた めにラジカルが消失する影響とが重なりあった結果として，観測されると考えられる.

\section{References}

Gosline, J. M., M. W. Denny \& M. E. Demont, 1984. Spider silk as rubber, Nature, 309: 551-552. OSAKI, S., 1989a. Thermal properties of spider's thread. Acta arachnol., 37: 69-75.

- 1989b. Seasonal change in color of spider's silk. Acta arachnol., 38: 21-28. 1994. Aging of spider silks. Acta arachnol., 43: 1-4. 1996. Spider silk as mechanical drag line. Nature, 384: 419.

WORK, R. W., 1976. The force-elongation behavior of orb-web fibers and silks forcibly obtained from orb-web-spinning spiders. Text. Res. J., 46: 485-492.

WORK, R. W. \& N. MOROSOFF, 1982. A physico-chemical study of the supercontraction of spider major ampullate silk fibers. Text. Res. J., 52: 349-356. 